ORIGINAL ARTICLE

\title{
When does self-improvement undermine materialistic tendencies, and when does it strengthen them?
}

\author{
Anna Maria Zawadzka \\ Institute of Psychology, University of Gdansk, Gdansk, Poland
}

BACKGROUND

In view of the fact that materialism may be caused by feelings of insecurity and low self-esteem, this paper attempts to answer the question of what the role of self-improvement is in the development of materialistic tendencies.

\section{PARTICIPANTS AND PROCEDURE}

Two experiments were carried out $(n=144, n=126)$. Half of the participants were exposed to self-threat (failure), which boosts materialistic tendencies, and the others were exposed to self-enhancement (success), which allows maintenance of good self-esteem. In both cases participants were given an opportunity to undertake self-improvement (i.e. redo a task that previously had turned out to be a failure/success). Analyses of materialistic tendencies were based on financial aspirations (study 1 ) and intentions to purchase luxurious good (study 2).
RESULTS

The results show that people have lower fiscal aspirations (study 1) and want to buy luxury products less (study 2) when they undertake self-improvement in a self-threat (failure) situation. However, when people undertake self-improvement in a self-enhancement situation (success) they have higher fiscal aspirations (study 1 ) and want to buy luxury products more (study 2).

\section{CONCLUSIONS}

Self-improvement may be an antidote to materialistic aspirations if undertaken in a self-threat situation, but it may also be a source of materialistic aspirations if undertaken in a self-enhancement situation.

KEY WORDS

self-enhancement; materialistic aspirations; self-improvement; self-threat

Corresponding AUthor - Anna Maria Zawadzka, Ph.D., Institute of Psychology, University of Gdansk, 4 Bażyńskiego Str., 80-309 Gdansk, Poland, e-mail: psyamz@ug.edu.pl

AUthors' CONTRiBution - A: Study design - B: Data collection - C: Statistical analysis - D: Data interpretation .

E: Manuscript preparation · F: Literature search · G: Funds collection

TO CITE THIS ARTICLE - Zawadzka, A. M. (2018). When does self-improvement undermine materialistic tendencies,

and when does it strengthen them? Current Issues in Personality Psychology, 6(1), 17-25.

RECEIVED 09.12.2016 · REVIEWED 19.01.2017 · ACCEPTED 03.04.2017 · PUBLISHED 08.12.2017 


\section{BACKGROUND}

Research on materialism, conducted for many years in different countries and cultures, clearly shows that materialism may have negative consequences for the welfare of individuals and societies (Dittmar, 1992; Kasser \& Ryan, 1993, 1996; Kasser, 2011; Richins \& Dawson, 1992; Burroughs \& Rindfleisch, 2002). Therefore, the search for its sources and antidotes has become a major challenge for researchers. Materialism is seen as a lifestyle in pursuit of wealth and ownership (Richins \& Dawson, 1992; Kasser \& Ryan 1993; Kasser, et al., 2004). Individuals focus on materialistic goals (e.g. financial success) at the expense of neglecting non-material goals (e.g. sense of competence) (Kasser \& Ryan, 1993). One of the main sources of materialism indicated by researchers is the feeling of insecurity (Kasser et al., 2004), which is linked with self-worth. Available studies demonstrate that materialism is associated with low self-esteem (Chaplin \& John, 2007; Park \& John, 2011; Zawadzka \& Iwanowska, 2016). A study conducted within the framework of symbolic self-completion theory indicated that a lack of competence that defines one's self may result in stronger yearning for goods that symbolise possession of such competence (Braun \& Wicklund 1989; Wicklund \& Gollwitzer, 1981). The study also showed that people may not only desire goods symbolising lack of competence but also prefer activities leading to acquisition of the competence. A single study conducted to date indicated that materialism is associated with low readiness for self-improvement (Zawadzka \& Iwanowska, 2016). In light of the above findings, the presented study is an attempt to answer the question of whether self-improvement actually undertaken in a self-threat situation affects materialistic tendencies (i.e. fiscal aspirations and preference for possession of prestigious goods) and, if so, how it affects them.

Scant studies on the influence of self-enhancement on materialistic tendencies show that in a self-enhancement situation people may be more materialistic and have a greater desire for prestige goods (Mandel, Petrova, \& Cialdini, 2001; Zawadzka \& Niesiobędzka 2010; Zawadzka, Strużyńska-Kujałowicz, \& Zawisza 2013). However, the question of how self-improvement affects materialistic tendencies in a self-enhancement situation has not been answered yet.

Therefore, the present study looks into the role of self-improvement in the growth of materialistic tendencies. It examines the following issues: a) how self-improvement influences materialistic aspirations and attitudes towards symbolic goods in a self-threat situation and b) how self-improvement influences materialistic aspirations and attitudes towards symbolic goods in a self-enhancement situation.

\section{SELF-THREAT SITUATION, ACQUISITION, AND POSSESSION VS. SELF-IMPROVEMENT}

Material goods have a symbolic nature because a certain social meaning (e.g. status) is attached to them (Dittmar, 1992; Ledgerwood, Liviatan, \& Carnevale, 2007). Money is also a means of attaining a higher status in the social system and is positively associated with social circumstances (i.e. social acceptance) (Lea \& Webley, 2006). Symbolic self-completion theory (Wicklund \& Gollwitzer, 1982) indicates that in a self-threat situation individuals may use material symbols of a specific competence to compensate for its absence. Furthermore, in a situation when the self-concept is incomplete people may use goods symbolising the desired self-concept. For example, Braun and Wicklund (1989) found that freshmen buy more items symbolising being a student than those who are about to graduate. Other research showed that in a self-threat situation material possessions may facilitate restoring the self through associations with the symbolic meaning of a specific product with the aspect of self-threat (Braun \& Wicklund, 1989; Wicklund \& Gollwitzer, 1981). Thus, in a self-threat situation people prefer and choose to buy those goods that relate to the threatened self-aspect (Cutright et al., 2011, Rucker \& Galinsky, 2008; Wicklund \& Golwitzer, 1982). Research done by Mazzocco, Rucker, Galinsky, and Anderson (2012) suggests that those who identify themselves with a lower social status group attach more importance to status goods. Other studies demonstrate that lack of power or status may increase the desire to possess status goods (Rucker \& Galinsky, 2008, 2009). Other researchers (Mead, Baumeister, Stillman, Rawn, \& Vohs, 2010) point out that when the self is threatened (by social exclusion) individuals prefer and are more eager to buy symbolic goods representing relationships and belongingness rather than utilitarian products or gifts for themselves. Moreover, according to yet another study, social exclusion makes it more important for people to possess money (Zhou, Vhos, \& Baumeister, 2009). According to Górnik-Durose (2002), when individuals fail (within the scope of efficiency) they set a greater value to the material goods they possess. Carr and Vignoles also observed that when the socio-economic status of an individual is uncertain they tend to use status symbols (2011). Similarly, people display stronger materialistic tendencies (i.e. they think that life success equals wealth and possessed goods) when their self is threatened (Chang \& Arkin, 2002). To sum up, the existing research shows that acquiring material goods or money may be of compensatory nature, which means that in self-threat situations accumulated goods may protect the self and, as a result, help to maintain self-worth and good self-esteem. 
Symbolic self-completion theory (Wicklund \& Gollwitzer, 1982) proposes that when the self is threatened individuals may not only use material goods to signify certain competences but they may also undertake activities linked to the threatened competences. Wicklund and Gollwitzer (1981) showed that teachers whose knowledge of the subject they teach is lacking declare willingness to work with a larger number of students. Furthermore, Mochon, Norton, and Ariely (2012) observed that persons who had experienced lack of sense of competence (while doing mathematical tasks) were more often inclined to get ready-to-assemble products and put them together themselves, when given a choice, than to have them assembled by the shop staff. This means that performing a 'substitute' activity may be a way to deal with self-threat and reestablish the sense of competence and, in turn, self-confidence. Another study demonstrated that when subjects failed to do a task in the area of a competence they considered important (i.e. an important aspect of self-concept), they did better in the next task (their efficiency increased in the next task) (Brunstein \& Gollwitzer, 1996). Kasser et al. (2014) carried out a study on teenagers and showed that self-improvement (i.e. participation in an educational financial program designed to orient individuals towards sharing and saving) increases self-esteem and decreases materialism. Another piece of research also confirmed the role of self-improvement in restoring self-worth (Green, Sedikides, Printer, \& Van Tongeren, 2009). Green et al. demonstrated that even though in order to build up self-esteem people tend to remember positive information about themselves better, they can remember both positive and negative information equally well when the concept of self-improvement is activated. To conclude, the obtained results indicate that even mere exposure to the concept of self-improvement is significant in restoring threatened self-worth.

Self-threat increases the desire for possessions (Chang \& Arkin, 2002; Rucker \& Galinsky, 2008, 2009) and undertaking self-improvement reduces self-threat (Mochion, Norton, \& Ariely, 2012; Green, Sedikides, Printer, \& Van Tongeren, 2009). Therefore, we hypothesised that H1: Undertaking self-improvement in a self-threat situation (failure) will lead to a decrease in fiscal aspirations and the intention to buy prestigious brands (as opposed to not undertaking self-improvement).

\section{SELF-ENHANCEMENT SITUATION, ACQUISITION, POSSESSIONS VS. SELF-IMPROVEMENT}

Studies on self-enhancement and materialistic tendencies (i.e. acquisition and possession) are scarce, but those available show that in a self-enhancement situation individuals desire prestigious goods and wealth more than when self-enhancement does not occur (cf. Mandel, Petrova, \& Cialdini, 2006; Zawadzka \& Niesiobędzka, 2010; Zawadzka \& Strużyńska-Kujałowicz, 2008; Zawadzka, Strużyńska-Kujałowicz, \& Zawisza, 2013). Mandel et al. (2006) studied how activation of success (the image of future success) affects financial expectations and preference for luxurious brands. They found that it contributes to an increase in income aspirations and preference for prestigious brands. Other research observed that self-enhancement boosted by activation of the sense of power leads to a rise in fiscal aspirations, i.e. participants primed with power want to earn more money and possess more investments and real estate (cf. Zawadzka \& Strużyńska-Kujałowicz, 2008; Zawadzka, Strużyńska-Kujałowicz, \& Zawisza, 2013). Another study showed that activation of an image of economic prosperity (i.e. self-enhancement) results in an increase in preference for symbolic value of goods as opposed to activation of an image of economic crisis (i.e. self-threat), which leads to an increase in preference for utilitarian value of goods (Zawadzka \& Niesiobędzka, 2010). Thus, the above results indicate that self-enhancement may induce a greater desire for the possession of prestigious goods. Within the existing gift-giving theories (cf. Belk 1979) Mick and DeMoss (1990) identified self-gifting. This behaviour was analysed (Mick \& Faure, 1998) in four achievement-related contexts (i.e. exam, sport, interview, speech) with feedback on success and failure corresponding to self-enhancement and self-threat respectively. The results showed that participants were more willing to reward themselves with material goods (gifts) when they had experienced a self-enhancement situation (i.e. success) and, at the same time, they felt a sense of pride, confidence, and happiness attributing the success to themselves. Accordingly, it is reasonable to assume that by self-gifting, individuals define the self, maintain positive self-image, and, through gifts, they also manifest self-attitudes. Self-gifting may be seen as both a reward for behaviour resulting in goal attainment and striving for a different self-image (cf. Bandura \& Perloff, 1967).

Following the findings that self-enhancement increases the preference for material goods (Zawadzka \& Strużyńska-Kujałowicz, 2008; Zawadzka, Strużyńska-Kujałowicz, \& Zawisza, 2013; Zawadzka \& Niesiobędzka, 2010; Mandel et al., 2006) and affects the relationship between undertaking self-improvement and self-gifting intentions (Mick \& DeMoss 1990), we made the second hypothesis H2: Undertaking self-improvement in a self-enhancement situation (success) will lead to an increase in fiscal aspirations and develop the intention to buy prestigious brands (as opposed to not undertaking self-improvement). 


\section{STUDY 1}

Study 1 was designed to test hypotheses $\mathrm{H} 1$ and H2. We raised the question of how undertaking self-improvement may affect fiscal aspirations linked to future possessions in a self-threat situation vs. self-enhancement situation. To check in what way undertaking self-improvement (ending in failure vs. success) can alter fiscal aspirations concerning future possessions (i.e. savings, real estate, and car) we created two priming situations: task failure (i.e. selfthreat) and task success (i.e. self-enhancement).

\section{PARTICIPANTS AND PROCEDURE}

\section{Participants}

One hundred forty fort participants, students at the Faculty of Social Sciences of the University of Gdańsk (aged $M=21.84, S D=1.56$ ), including 75 men and 69 women, were surveyed. We conducted the survey during psychology classes, and the participants received credits for participation in the study.

\section{Independent variables}

Activation of self-threat (failure) and self-enhancement (success). To create situations of failure and success we asked participants to do tasks in geometric shapes testing deduction skills, similar to those previously used in other research (cf. Kurman, 2006). In the failure situation task participants had to answer a selection of 10 difficult questions from Raven's Matrices, and in the success situation task participants had to answer a selection of 10 easy questions.

\section{Dependent variables}

Fiscal aspirations. We measured fiscal aspirations with three closed-ended questions, a method used in previous research (cf. Kasser \& Sheldon, 2000). Participants were asked to answer the following questions about their future in 10 years: 1 . How much money do you expect to have saved? (four possible answers): a) PLN $^{1} 10,000-20,000$, b) PLN 20,000-40,000, c) PLN $80,000-100,000, d)$ more than PLN 100,000); 2 . How much money do you expect to pay for the real estate (apartment/house) you will consider good enough to settle in? (six possible answers): a) not more than PLN 70,000, b) PLN 70,000-100,000, c) PLN 101,000200,000, d) PLN 201,000-350,000, e) PLN 351,000500,000 , f) more than PLN 500,000; 3 . How much money do you expect to pay for your car (that you will consider good enough)? (six possible answers): a) not more than PLN 10,000, b) PLN 10,000-30,000, c) PLN 30,000-70,000, d) PLN 70,000-120,000, e) PLN 120,000-250,000, f) more than PLN 250,000.

\section{Procedure}

Participants were surveyed individually. To conceal the real aim of the study, we asked participants at the beginning of the session to indicate adjectives that describe them from a list. Then, they were randomly assigned to one of two groups. The first group completed easy patterns with missing elements, and they could take as much time as they needed to finish the task. The second group did difficult patterns and their time was limited so that they could not finish the task on time. Next, the experimenter used a key to calculate the score and informed the participants about their results: in the first group "your score is more than $75.00 \%$ " and in the second group "your score is less than 25.00\%". Afterwards, the experimenter said that she needed some time to prepare another test and she suggested in the first group that the participants do another similar test in the meantime whereas in the second group she suggested that participants retake the test to get a better score. The experimenter noted down whether the participants had chosen to do the optional activity or not. Finally, each participant answered the fiscal aspirations questionnaire.

\section{RESULTS AND DISCUSSION OF STUDY 1}

The effect of group (failure vs. success) and self-improvement on fiscal aspirations. We carried out analysis of variance in the following inter-group comparison project: 2 (group: task failure vs. task success) $2 \times$ (self-improvement: undertaking vs. not undertaking). The main effect of self-improvement was identified for aspirations concerning the value (price) of a future car. The effect was significant at tendency level: $F(1,137)=2.81, p=.096, \eta^{2}=.02$.

More importantly, there was a significant group effect and self-improvement interaction effect for aspirations concerning the value of future real estate $\left(F(1,137)=9.47, p=.003, \eta^{2}=.07\right)$ and future savings $\left(F(1,137)=3.21, p=.075, \eta^{2}=.02\right)$.

Planned comparisons demonstrated significant differences in the success sample between the participants who had undertaken self-improvement and those who had not when future real estate $(M s s=4.21, S D=1.32, M s n s=3.16, S D=1.38 ; t(70)=$ $-3.20, p=.010)$ and a future car $(M s s=3, S D=1.22$, Msns $=3.65, S D=1.03 ;(t(70)=-2.31, p=.050)$ were involved. Significant differences also occurred between groups primed with success and with failure that had not undertaken self-improvement concerning the value of future real estate $(M s=3.16$, $S D=1.38, M f=3.83, S D=1.26 ; t(82)=-2.30$, $p=.020)$ and future savings $(M s=2.77, S D=1.26$, $M f=3,22, S D=1.27 ; t(82)=-1.64, p=0.100-$ significance at tendency level). Furthermore, we observed significant differences were participants primed 
with success and with failure, who had undertaken self-improvement when future real estate was involved $(M s=4.21, S D=1.32, M f=3.47, S D=1.46$; $t(56)=2.05, p=.050)$ (See Figure 1 and Figure 2). We found no significant effect in fiscal aspirations referring to the price of the desired car $F<1$ n.s.

\section{MANIPULATION CHECK}

Before testing the hypotheses, we had checked whether the tasks had different levels of difficulty. In order to do this, we compared the time the participants needed to do the tasks in a situation of failure and in a situation of success. The difference was statistically significant $(t 56)=-7.55, p<.001, M s=4.21 \mathrm{~min}$., $S D=2.34, M f=10.71$ min., $S D=3.94)$. The time required to do the tasks was much longer in a failure situation than in a success situation.

The obtained results indicating the interaction effect in the case of fiscal aspirations in connection with real estate and savings confirmed hypothesis H1. The said effect is the effect of self-improvement on the increase of fiscal aspirations of participants undertaking self-improvement following a success. Hypothesis H2 was partially confirmed. The results demonstrated that fiscal aspirations (value of future real estate and savings) became more significant for participants who had not undertaken self-improvement in a situation of failure as compared to a situation of success. However, for those who did undertake self-improvement the relationship was reversed - fiscal aspirations became more significant in a situation of success as compared to a situation of failure.

\section{STUDY 2}

The aim of study 2 was to double-check the results obtained in study 1 ; hypotheses $\mathrm{H} 1$ and $\mathrm{H} 2$ were verified again. In this study, we modified both the way self-threat and self-enhancement were activated and the operationalisation (measurement) of materialistic aspirations. We analysed how self-improvement may affect preferences for purchase of prestige goods (brand) in a self-threat vs. self-enhancement situation.

\section{PARTICIPANTS AND PROCEDURE}

\section{Participants}

One hundred twenty six participants, students at the Faculty of Social Sciences of the University of Gdańsk (aged $M=21.11, S D=2.40$ ), including 63 women and 63 men, were surveyed. We conducted the survey during psychology classes, and the participants received credits for participation in the study.

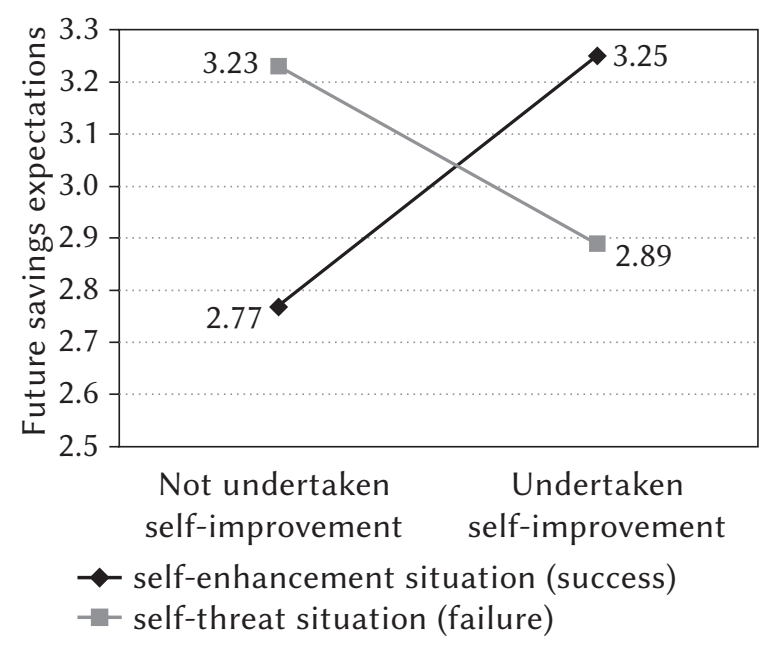

Figure 1. Future savings expectations in self-enhancement and self-threat situations when given an opportunity for self-improvement.

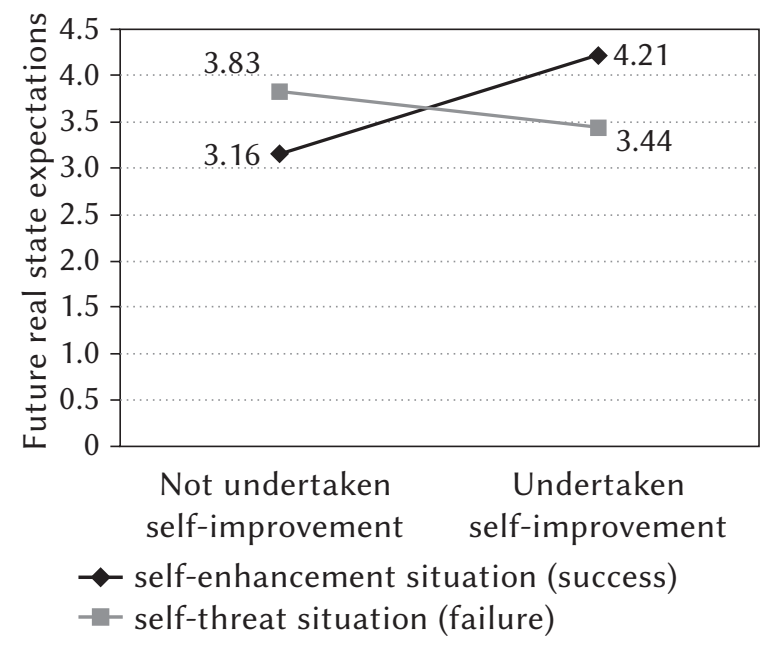

Figure 2. Future real state expectations in self-enhancement and self-threat situations when given an opportunity for self-improvement.

\section{Independent variables}

Activation of self-threat (failure) and self-enhancement (success). To activate success and failure we used selected tasks (i.e. verbal, spatial, and mathematical problems) from creativity test (Dow \& Mayer, 2004). In a success situation participants were asked to do easy tasks while in a failure situation they were asked to do complex tasks.

\section{Dependent variables}

Measurement of preferences for prestige brand purchases. In order to determine how people perceive the brands of selected products we carried out a pilot study. We surveyed 59 students (24 men and 35 women, aged $M=21.30 S D=2.40$ ); they did not participate in the major study. The participants were asked to judge the status of selected clothing brands 
and car makes using a 100-item scale from 1 (low status) to 100 (high status). In clothing brands, Calvin Klein $(84,16)$ and Gucci $(94)$ were granted high status and H\&M $(45,4)$ and Reserved $(52,2)$ middle status, while in car brands Lexus (92.9) and Maybach (93.9) were granted high status and Fiat (40) and Opel (51) middle status. Therefore, two brands Calvin Klein (T-shirt) and Lexus (car) were chosen for the major study; all participants were familiar with the brands used.

In the study the participants were asked questions about their purchase preferences concerning prestigious car brands (Lexus) and clothing brands (Calvin Klein). They marked their answers on a seven-item scale (where 1 is I definitely wouldn't buy this car/ clothing brand and 7 is I would definitely buy this car/ clothing brand).

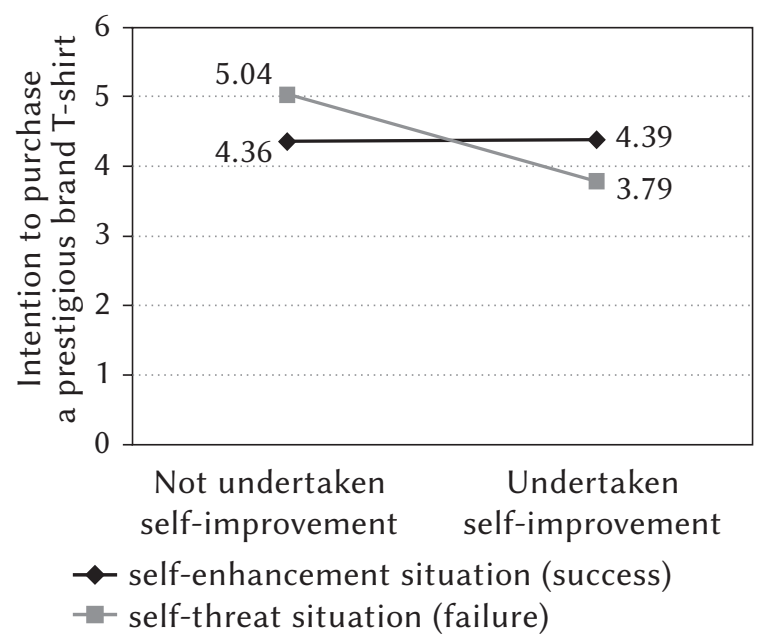

Figure 3. The intenton to purchase a prestigious brand T-Shirt in self-enhancement and self-threat situations when given an opportunity for self-improvement.

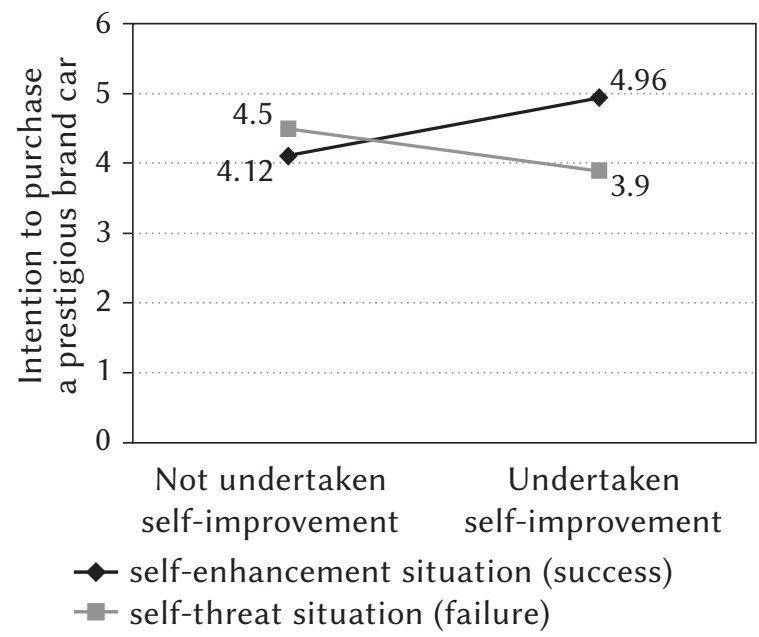

Figure 4. The intenton to purchase a prestigious brand car in self-enhancement and self-threat situations when given an opportunity for self-improvement.

\section{PROCEDURE}

We assigned the subjects to two random groups: success group and failure group. In the success group the participants were asked to do five tasks within five minutes. Next, an assistant calculated the score and, regardless of the result, gave each of the participants the same feedback: "Your score is above average. Well-done - congratulations! If you wish, you can do an additional task (i.e. complete geometric figures from another test, you can pick the figures yourself) and get an even better score, or you can move on to the third part of the study. What's your decision?" In the failure group the participants were asked to do five tasks within 10 minutes. When the time was over, all the participants were given identical feedback: "Your score is below average. Unfortunately, it is too bad. [a pause] If you wish, you can redo the tasks and indicate different answers about the figures that you can pick yourself, or you can move on to the third part of the study. What's your decision?" Following this manipulation, the participants filled in questionnaires including purchase preference scales concerning prestigious and non-prestigious brands. In order to conceal the purpose of the study, the subjects were asked additional questions about their purchase preferences for non-prestigious brands (cars: Fiat and Opel, clothes: H\&M and Reserved).

\section{RESULTS AND DISCUSSION OF STUDY 2}

The effect of group (failure vs. success) and self-improvement on the intention to purchase prestigious brands. We performed analysis of variance on the project of $2 \times$ (group: task failure vs. task success) $2 \times$ (self-improvement: undertaken vs. not undertaken) inter-group comparisons. A group effect and self-improvement interaction effect were present for the intention to purchase both prestigious brands: Lexus $\left(F(1,118)=3.91, p=.050, \eta^{2}=.03\right)$ and Calvin Klein $\left(F(1,118)=3.29, p=.070, \eta^{2}=.27\right)$. Also, a main effect at statistical tendency level $(F(1,118)=3$, $p=.080)$ was noted for self-improvement and the intention to purchase Calvin Klein branded clothing.

Planned comparisons indicated significant differences in the failure group for the intention to purchase Calvin Klein branded clothing between the participants who had undertaken self-improvement $(M=5.04, S D=1.82)$ and those who had not $(M=3.79, S D=1.96, t(59)=2.56, p=.010)$. Moreover, we found a significant difference for the intention to purchase a Lexus car in participants who had undertaken self-improvement between those primed with success $(M=4.96, S D=2.20)$ and those primed with failure $(M=3.91, S D=1.91, t(59)=-2.004, p=.050)$ (See Figure 3 and Figure 4). 


\section{MANIPULATION CHECK}

We analysed the difference between the number of completed tasks in the success and in the failure group. The difference was statistically significant $(t(120)=-14.70, p<.001, M s=4.02, S D=0.79$, $M f=1.72, S D=0.93)$. Participants in the success group completed four out of five tasks on average within the time limit given, while participants in the failure group completed fewer than two out of five tasks. This demonstrates that the manipulation was sufficient.

Study 2 demonstrated that the assumed effect of self-improvement and situation interaction was statistically significant, which means that hypotheses $\mathrm{H} 1$ and $\mathrm{H} 2$ were confirmed in this study, too. The acquired effect included the effect of undertaking self-improvement on the decrease of the intention to purchase prestigious brands (clothing) in a selfthreat situation (failure) and the effect of undertaking self-improvement on the increase of the intention to purchase prestigious brands (car) in a self-enhancement situation (success).

\section{DISCUSSION AND CONCLUSIONS}

This paper presents research that looks into the role of self-improvement in the growth of materialistic aspirations. Its results indicate that undertaking self-improvement does matter in developing materialistic aspirations. The way in which self-improvement affects materialistic aspirations depends on the situation in which it is undertaken - in a self-threat situation self-improvement decreases materialistic aspirations whereas in a self-enhancement situation it increases them. Moreover, undertaking self-improvement in a failure situation results in lower materialistic aspirations (i.e. people are less interested in buying prestigious brands, study 2) as compared to not undertaking self-improvement. However, if self-improvement is undertaken in a success situation, fiscal aspirations increase (i.e. people want to own real estate in the future, study 1 , and they want to buy prestigious brands, study 2) as compared to not undertaking self-improvement. What is more, people who undertake self-improvement in a success situation want to have more real estate than those who undertake self-improvement in a self-threat situation (study 1).

Available research shows that when confronted with a threat to the self (e.g. lack of knowledge or competence) people can restore their self-worth not only through acquisition of material goods but also by engaging in activities that boost self-confidence (cf. Mochon, Norton, \& Ariely, 2012), The presented study demonstrates that self-improvement (i.e. improving task performance after failure) is an activity that inhibits the growth of the significance of materi- al goods. This accords with the research of predecessors showing that self-improvement plays a significant part in restoring self-worth (Green et al., 2009).

Another finding of this study is that when people are successful in proving a competence (as in a self-enhancement situation), self-improvement has the opposite effect because it increases materialistic aspirations. According to previous research, people tend to reward themselves with material goods in achievement/success situations (Mick \& Faure, 1998). Furthermore, the presented study indicates that repeating a successful performance of a task leads to an increase in materialistic aspirations. Thus, it can be assumed that undertaking an extra effort in a self-enhancement situation triggers self-gifting which, if customary, may strengthen materialistic aspirations. Also, prior studies revealed that there is a link between the weight of achievement and materialistic aspirations (Burroughs \& Rindfleisch, 2002). The results presented in this paper go further and prove experimentally that undertaking self-improvement in a success situation (i.e. when having already achieved, people want to achieve more by undertaking self-improvement) contributes to the increase in materialistic aspirations.

In must also be mentioned that the tested hypotheses (concerning the link between self-improvement and the effect of self-threat activation on materialistic preferences) have not been confirmed in the case of some measures of materialistic aspirations selected for this study. Self-improvement in a self-threat situation resulted in a desire for prestigious clothing brands while self-improvement in a self-enhancement situation resulted in both fiscal aspirations (i.e. real estate and savings) and desire for prestigious car brands. Also, the price of a car turned out to be less significant for self-enhancement consumption than its prestigious brand. In other words, the results suggest that the examined measures of materialistic aspirations, i.e. prestigious goods (e.g. clothing) and wealth (e.g. real estate or savings), could have served different purposes in the self-concept management of the participants. Therefore, the monetary value and prestige value of a product brand may carry different meanings. Another thing worth mentioning is that some of the obtained statistical significances are at tendency level, which means that they should be interpreted with caution (e.g. the price of a future car as a measure of materialistic tendencies).

\section{DIRECTIONS FOR FUTURE RESEARCH}

On the basis of the results presented in this paper, we recommend the following directions for future research: first, research into the effect of self-improvement on materialistic aspirations in a self-threat situation and in a self-enhancement situation using 
various measures of materialistic aspirations (e.g. those connected with material goods and those connected with financial wealth); second, longitudinal studies on how materialistic aspirations evolve in individuals exposed to self-threat situations (i.e. failure) vs. self-enhancement situations (i.e. success) when they undertake self-improvement and when they do not; third, answering the question of whether self-enhancement (i.e. success) in a materialistic environment may be a reward in itself or whether it always requires some material reward. Furthermore, bearing in mind the fact that self-improvement may involve activities linked with different spheres of life, e.g. improving one's skills or traits (cf. Taylor, Neter, \& Wayment, 1995), future research should address the question of whether there is a self-improvement activity that may result in decreasing materialistic aspirations when undertaken in a self-enhancement situation. To put it simply, what is the antidote to rising materialistic aspirations in a self-enhancement situation?

In conclusion, the results obtained in this study indicate that self-improvement may have a twofold effect on developing materialistic preferences: it may decrease materialistic preferences when self-improvement is undertaken in a self-threat situation, or it may increase materialistic preferences when self-improvement is undertaken in a self-enhancement situation.

\section{ENDNOTES}

1 The average monthly net earnings are around PLN 3000.

\section{REFERENCES}

Bandura A., \& Perloff, B. (1967). Relative efficacy of self-monitored and externally-imposed reinforcement systems. Journal of Personality and Social Psychology, 7, 111-116

Belk, R. W. (1979). Gift-Giving Behaviour. In J. Sheth (Ed.), Research in Marketing (Vol. 2, pp. 95-126). Greenwitch, CT: JAI Press.

Braun, O. L., \& Wicklund, R. A. (1989). Psychological Antecedents of Conspicuous consumption, Journal of Economic Psychology, 10, 161-187

Brunstein, J. C., \& Gollwitzer, P. M. (1996). Effects of failure on subsequent performance: The importance of self-defining goals. Journal of Personality and Social Psychology, 70, 395-407.

Burroughs, J. E., \& Rindfleisch, A. (2002). Materialism and well-being: conflicting values perspective. Journal of Consumer Psychology, 29, 348-370.

Carr, H. L., \& Vignoles, V. L. (2011). Keeping up with the Joneses: Status projection as symbolic self-completion. European Journal of Social Psychology, 41, 518-527. doi: 10.1002/ejsp.812
Chang, L., \& Arkin, R. M. (2002). Materialism as an attempt to cope with uncertainty. Psychology and Marketing, 19, 389-406.

Chaplin, N. L, \& John, D. R. (2007). Growing up in a material world: Age differences in materialism in children and adolescents. Journal of Consumer Research, 34, 480-493.

Cutright, K. M., Wu E. C., Banfield, J. C., Kay A. C., \& Fitzsimons, G. J. (2011). When your word must be defended: choosing product to justify the system. Journal of Consumer Research, 38, 62-77. doi: $10.1086 / 658469$

Dittmar, H. (1992). The social psychology of material possessions: to have is to be. New York: Harvester Wheatsheaf, Hemel Hempstead and St Martin's Press.

Dow, G. T., \& Mayer, R. E. (2004). Teaching students to solve insight problems. Evidence for domain specifity in training. Creativity Research Journal, 16, 389-402.

Górnik-Durose, M. (2002). Psychologiczne aspekty posiadania między instrumentalnościq a spoteczna użytecznościa dóbr materialnych [Psychological Aspects of Possession - between Instrumentality and Social Utility of Material Goods]. Katowice: Wydawnictwo Uniwersytetu Śląskiego.

Green, J. D., Sedikides, C., Pinter, B., \& Van Tongeren, D. (2009). Two sides to self-protection: self-improvement strivings and feedback from close relationships eliminate mnemic neglect. Self-and Identity, 8, 233-250.

Kasser, T., \& Ryan, R. M. (1993). A dark side of an American dream: Correlates of financial success as a central life aspiration. Journal of Personality and Social Psychology, 65, 410-422.

Kasser, T., \& Ryan, R. M. (1996). Further examining the American dream: Differential correlates of intrinsic and extrinsic goals. Personality and Social Psychology Bulletin, 22, 280-287.

Kasser, T., \& Sheldon, K. M. (2000). Of Wealth and Death: Materialism, Mortality Salience, and Consumption Behavior. Psychological Science, 11, 348-351.

Kasser, T. (2011). Cultural Values and the Well-Being of Future Generations: A Cross-National Study. Journal of Cross-Cultural Psychology, 42, 206-215. doi: 10.1177/0022022110396865

Kasser, T., Sheldon, K. M., Ryan, R. M., \& Deci, E. L. (2004). The Independent Effects of Goal Contents and Motives on Well-being: It's Both What You Do and Why You Do It. Personality and Social Psychology Bulletin, 30, 475-486.

Kasser, T., Rosenbleu K. L, Saneroff A. J., Deci E. J., Niemiec C. P., Ryan R. M., ...Hawks S. (2014). Changes in materialism, changes in psychological well-being: evidence from three longitudinal studies an intervention experiment. Motivation and Emotion, 38, 1-22. doi: 10.1007/s1031-013-9374-4 
Kurman, J. (2006). Self-enhancement, self-regulation and self-improvement following failures. British Journal of Social Psychology, 45, 339-356.

Lea, S. E., \& Webley, P. (2006). Money as tool, money as drug: the biological psychology of a strong incentive. Behavioral Brain Science, 29, 161-176. doi: 10.1017/S0140525X06009046

Ledgerwood, A., Liviatan, I., \& Carnevale, P. J. (2007). Group-identity completion and the symbolic value of property. Psychological Science, 18, 873-878.

Mazzocco, P. J., Rucker, D. D., Galinsky, A. D., \& Anderson E. T. (2012). Direct and vicarious conspicuous consumption: identification with low-status group increases the desire for high-status goods. Journal of Consumer Psychology, 22, 520-528. doi: http://dx.doi.org/10.1016/j.jeps.2012.07.002

Mead, N. L., Baumeister, R., Stillman T. F., Rawn C. D., \& Vhos, K. D. (2010). Social Exclusion causes people to spend and consume strategically in service of affiliation. Journal of Consumer Research, 37, 902-919.

Mandel N., Petrova, P. K., \& Cialdini, R. B. (2006). Images of success and the preference for luxury brands. Journal of Consumer Psychology, 16, 57-69.

Mick, D. G., \& Faure, C. (1998) Consumer self-gifts in achievement contexts: The role of outcomes, attributions, and deservingness. International Journal of Research in Marketing, 15, 293-307.

Mick, D. G., \& Demoss, M. (1990). Self-Gifts: Phenomenological Insights from Four Contexts. Journal of Consumer Research, 17, 322-332.

Mochon, D., Norton, M. J., \& Ariely, D. (2012). Bolstering and restoring feelings of competence via lkea effect. International Journal of Research in Marketing, 29, 363-269. doi: 10.1016/j.yresmar2012.05.001

Park, J. K., \& John, D. R. (2011). More than meets the eye: the influence of implicit and explicit self-esteem on materialism. Journal of Consumer Psychology, 21, 73-87.

Richins, M. L., \& Dawson, S. (1992). A consumer values orientation for materialism and its measurement: Scale development and validation. Journal of Consumer Research, 19, 303-316.

Ryan, R. M., \& Deci, E. L. (2000). Self-determination theory and the facilitation of intrinsic motivation, social development, and well-being. American Psychologist, 55, 68-78.

Rucker, D. D., \& Galinsky, A. D. (2009). Conspicuous consumption versus utilitarian ideals: How different levels of power shape consumption. Journal of Experimental Social Psychology, 45, 549-555.

Rucker, D. D., \& Galinsky, A. D. (2008). Desire to acquire: Powerlessness and compensatory consumption. Journal of Consumer Research, 35, 257267.

Taylor, S. E., Neter, E., \& Wayment, H. A. (1995). Self-evaluation processes. Personality and Social Psychology Bulletin, 21, 1278-1287.
Wicklund, R. A., \& Gollwitzer, P. M. (1981). Symbolic self-completion, attempted influence, and self-deprecation. Basic and Applied Social Psychology, 2, 89-114.

Wicklund, R. A., \& Gollwizter, P. M. (1982). Symbolic self-completion. Hillsdale, NJ: Erlbaum.

Zawadzka A. M. (2014). The scale of readiness for self-improvement: an analysis of its internal consistency, theoretical validity and reliability. Acta Neuropsychologica, 12, 73-84.

Zawadzka A. M., \& Niesiobędzka M. (2010). Preferencje konsumenckie w kryzysie i rozwoju gospodarczym z perspektywy samoregulacji [Consumer Preferences in Time of Economic Crisis and Growth from Self-regulatory Perspective]. Czasopismo Psychologiczne, 16, 253-264.

Zawadzka A. M., Strużyńska-Kujałowicz A., \& Zawisza M. (2013). The effects of power on financial aspirations and expenditures on selected product categories in Poland and the UK. Journal of Social Research and Policy, 4, 41-58.

Zawadzka A. M., \& Iwanowska M. (2016). Explicit and implicit materialism vs. self-esteem and readiness for self-improvement in young people. Annals of Psychology, 19, 697-740. doi: http://dx.doi. org/10.18290/rpych.201619.4-3pl

Zhou, X., Vhos, K. D., \& Baumeister, R. F. (2009). The symbolic power of money. Reminders of Money Alter social Distress and Physical Pain. Psychological Science, 20, 700-706. 